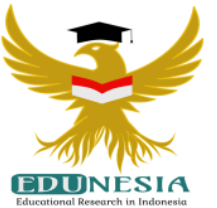

\title{
Implementation of Blended Learning During COVID-19 Pandemic on Civic Education Subjects in Millenial Generation Era
}

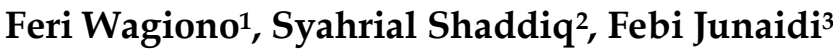 \\ ${ }^{1}$ Teacher of Civic Education, Junior High School of Muhammadiyah 1 Kroya (Musaka) Cilacap, Indonesia \\ ${ }^{2}$ Management, University of Cahaya Bangsa (yoUCB) Banjarmasin, Indonesia \\ ${ }^{3}$ Indonesian Language Education, University of Sebelas Maret (UNS) Surakarta, Indonesia \\ ${ }^{1}$ Corresponding Email: wagionoferi456@gmail.com, Phone Number: 0812 xxxx xxxx
}

\author{
Article History: \\ Received: Nov 27, 2021 \\ Revised: Dec 06, 2021 \\ Accepted: Dec 10, 2021 \\ Online First: Dec 15, 2021
}

\section{Keywords:}

Blended Learning with characters, the pandemic of COVID-19, millennials

Kata Kunci:

Blended Learning bermuatan karakter,

masa pandemi COVID-19,

Generasi millenial.

\footnotetext{
How to cite:

Wagiono, F., Shaddiq, S., \& Junaidi, F. (2022). Implementation of Blended Learning During COVID-19 Pandemic on Civic Education Subjects in Millenial Generation Era. Edunesia: Jurnal Ilmiah Pendidikan, 3 (1): 36-44.
}

This is an open access article under the $C C-B Y-N C-N D$ license

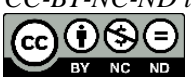

\begin{abstract}
This article was written related to the Indonesian government's policies during the COVID-19 emergency, triggering innovation in learning. The complexity of implementing distance learning (PJJ) in the 4.0 era creates new problems, especially for the education of students in secondary schools. The learning process has changed drastically. Blended learning in education is not only face-to-face but also integrated online learning from home. The purpose of this article is to discuss the application of blended learning-based learning during the COVID-19 pandemic subject matter for Pancasila and Civic Education (PPKn) for millennial generations students of Junior High School Muhammadiyah 1 Kroya with character. This research is qualitative. The research subjects consisted of the principal, 2 PPKn teachers, and 46 grade 8 students of SMP Muhammadiyah 1 Kroya. Data collection techniques in the study used interview, documentation, and observation techniques. Data analysis techniques are reduction, collection, presentation of data, and conclusions. The implementation of blended learning during the COVID-19 pandemic at SMP Muhammadiyah 1 Kroya was carried out in several stages, namely presentation/planning, implementation, student discussion guidance, practice, elaboration, demonstration, and student evaluation related to PPKn.
\end{abstract}

\footnotetext{
Abstrak: Artikel ini ditulis terkait kebijakan pemerintah Indonesia dalam masa darurat COVID-19 memicu untuk berinovasi dalam pembelajaran. Kompleksitas pelaksanaan pembelajaran jarak jauh (PJJ) di era 4.0 menimbulkan masalah baru, terutama bagi pendidikan siswa di sekolah menengah. Proses pembelajaran telah berubah secara drastis. Pembelajaran blended learning pada pendidikan bukan hanya tatap muka melainkan juga diintegrasikan belajar daring dari rumah. Tujuan artikel ini ialah penerapan pembelajaran berbasis blended learning masa pandemi COVID-19 materi pelajaran Pendidikan Pancasila dan Kewarganegaraan (PPKn) generasi millenial siswa SMP Muhammadiyah 1 Kroya bermuatan karakter. Penelitian ini bersifat kualitatif. Subjek penelitian terdiri dari kepala sekolah, 2 guru PPKn dan 46 siswa kelas 8 SMP Muhammadiyah 1 Kroya. Teknik pengumpulan data dalam penelitian menggunakan teknik wawancara, dokumentasi dan pengamatan. Teknik analisis data yaitu reduksi, pengumpulan, penyajian data dan kesimpulan. Pelaksanaan penerapan pembelajaran blended learning selama pandemi COVID-19 di SMP Muhammadiyah 1 Kroya dilakukan dalam beberapa tahap yaitu presentasi/perencanaan, pelaksanaan, bimbingan diskusi siswa, praktik, elaborasi, demonstrasi, dan evaluasi siswa terkait materi PPKn.
} 


\section{A. Introduction}

Corona virus Diseases-19 (COVID-19) pandemic has an impact on various aspects of education. Indonesia is making efforts to handle and prevent the spread of the COVID-19 virus. Efforts to prevent the spread of COVID-19 are carried out by the Indonesian government in the aspect of education. Indonesian government policy to dissolve learning activities in schools. Therefore, the government and educational institutions are trying to find ways to keep teaching and learning activities active even during a pandemic. Teaching and learning activities during the COVID-19 pandemic that were previously carried out in schools, changed to learning from home through online learning or electronic learning (elearning). This is by the Circular Letter of the Minister of Education No. 4 of 2020 on the Implementation of Education Policy in the COVID-19 Emergency Period to carry out the learning process from home or use e-learning (Aritonang et al., 2021). Learning instead is done online or e-learning that advocates being implemented from home or distance learning (PJJ). The online learning process or PJJ is done using various applications such as WhatsApp, zoom, google meet, Microsoft teams, and google classroom (Rizal et al., 2020).

Government regulations on the implementation of distance learning are not fully enforced in some areas. Areas in the green zone category are allowed to carry out face-toface learning despite limited time and must implement health protocols. The COVID-19 task force recorded data on the covid_19.go.id page as of June 23, 2021, that the total positive confirmation cases of COVID-19 amounted to 2,033,421 cases, cases died as many as 55,594 cases, and were declared cured a total of $1,817,303$ people spread across 34 provinces in Indonesia. The COVID-19 pandemic has resulted in various aspects, one of which is the learning process in education. This is what makes principals and educators in the green zone area innovate learning. One of the innovations made by the school is to carry out blended learning. Blended learning is a type of learning that refers to teaching and learning activities that combine or mix between face to face learning and online-based learning (Suhartono, 2016). The process of face-to-face learning has lost its appeal in the 21st century. This is because some learners think with the development of increasingly sophisticated technology, so blended learning is very suitable when used as a learning model in the 21st and future eras conducted online (e-learning). To apply the development of technology (e-learning) to the younger generation without having to leave face-to-face learning but there is also a strategy of organizing teaching, teaching delivery, and the right quality of teaching, namely with Blended Learning in era 4.0 (Afandi, Chamalah, dan Wardani, 2018; Rizal et al., 2020; Fadilurrahman et al., 2021).

According to Wahana (2015), Millennials are the younger generation who are currently synonymous with gadget technology culture at a time of important phenomenon of the current globalization process (Wahana, 2015; Wanidison dan Shaddiq, 2021). Gadgets are interpreted from the perspective of the device, it can be understood that the generation of gadgets is the generation that is always in contact with devices that contain elements of information technology. So as if these tools had become an integral part of their lives, technological tools seemed to be an important part of their lives (Petrova, \& Podzygun, 2018).

Research on the impact and use of the internet is a major source of information about what's going on in the world, such as entertainment, fun, relaxation, forgetting problems, eliminating loneliness, and filling time with friends and family. The Internet has many advantages, especially when it comes to communicating and extracting information across a community of artificial intelligence-based internet users, including teenagers (Emi, 2015; 
Wagiono et al., 2020; Iyansyah et al., 2021; Shaddiq et al., 2021). The Internet can quickly obtain information using Google and other means, but most teens use the internet as a medium of communication to make friends, chat, and send emails or do homework at universities and schools (Černá \& Svobodová, 2015; Shaddiq et al., 2021; Wijaya et al., 2021). The most popular among teenagers today are WhatsApp, Instagram, TikTok, Friendster, Facebook, Twitter and others. They look for friends on Instagram and Facebook, and can also send photos and others (Kalida, 2015; Arizal et al., 2021).

In Indonesia's millennial era today, internet users often override morals and ethics. Values that need to be applied when you want to communicate, until the end of a dispute such as saying harsh words on social media. Phenomena associated with uncontrolled activities of the younger generation form negative personalities such as individualism, arrogance, looking down on the potential of others, and not appreciating differences.

Civic education (PPKn) efforts for millennials need to be strengthened in everyday life. It aims to improve the quality of teenage personality. From the cultural aspect of manners and manners, responsible, appreciating the process, and fighting spirit that must always be trusted and built (Hamidi, 2010). The aim is to prepare credible, intelligent, and good young citizens to fill independence with active and effective participation for citizens and the country to look forward to a brighter future. Creating a young generation who are noble and personal for a better Indonesia following the values of Pancasila and the 1945 Constitution. PPKn is a means of equipping learners with basic knowledge and skills about the relationship between citizens and nations, love of the homeland, and training them to become democratic citizens (Wuryan dan Syaifullah, 2008; Wagiono et al., 2020).

A blended learning model that combines face-to-face and online activities. In its application, such learning reduces direct learning in the classroom. According to Prayitno (2015), that the goal of using this learning model is to help millennial students become more independent and active in learning. The advantage of this learning model is that teachers can provide learning materials anytime and anywhere. Offline and online learning complement each other, learning becomes effective and efficient, teacher and student interaction is well established, accessibility is improved, and learning is flexible (Prayitno, 2015). Blended learning is very important because it can support students in mastering the material delivered at online meetings during COVID-19. The important thing to consider is the characteristics of blended learning applied. In context, students use health protocols, maintain personal and environmental hygiene, and keep their distance from each other. The duration of the implementation time is limited as usual. Although limited, blended learning can be a place for strengthening understanding, passion, can increase students' sense of responsibility, student learning outcomes, and student motivation to learn during pandemic times (Suhartono, 2016; Khoiroh et al., 2017).

The purpose of this scientific article is to apply, develop and provide blended learning PPKn material to millennial youth at Junior High School of Muhammadiyah 1 Kroya. In addition, optimal utilization of digital media (gadgets) is very beneficial for students in school.

\section{B. Method}

This research is qualitative. This is based on the type of survey data in the form of qualitative data. This research has research subjects of principals, teachers, and students of Muhammadiyah 1 Kroya Junior High School. The research subject is the main source of research data, including the variable data studied (Simonson, 2016). SMP Muhammadiyah 
1 Kroya has NIS 5648 and NPSN 20300506 Mujur street, Kroya subdistrict, Cilacap Regency, Central Java province. Data research is information about the application of blended learning models during the COVID-19 pandemic loaded with the character of millennials' PPKn subject matter at Muhammadiyah 1 Kroya Junior High School. Research data sources are grouped into two types, informant and documentation. Informant consists of the principal, 2 Civic education teachers who teach students, and 46 students of 8th-grade Junior High School of Muhammadiyah 1 Kroya consisting of 26 male students and 20 female students. Online documentation of the application of blended learning during the COVID19 pandemic of millennials' PPKn subject matter at Muhammadiyah 1 Kroya Junior High School.

The data collected in this study uses interviews, observations, and documentation. The informant interviewed was the principal, teacher, and student of Muhammadiyah 1 Kroya Junior High School who studied with gadgets. Interview techniques are used to explore data on PPKn learning at Muhammadiyah 1 Kroya Junior High School. In-depth interview with the principal, 2 teachers, and 46 students of Muhammadiyah 1 Kroya Junior High School. Observations were made on how the readiness of teachers in learning PKn students at Muhammadiyah 1 Kroya Junior High School. Documentation in the form of research reports on daily journals and assessment journals of student learning devices application of blended learning materials PPKn millennial generation in Muhammadiyah 1 Kroya junior high school. Validity of data in this study using triangulation (Moser \& Korstjens, 2018). Data analysis techniques are performed such as data reduction, data collection, data presentation, and conclusion withdrawal or verification.

\section{Result and Discussion \\ Learning of Civic Education (PPKn) for Millennials}

The importance of learning Civic Education (PPKn) in schools, explains the behavior of citizens, ways of thinking, all citizen behavior, rights and obligations, ideals and aspirations, awareness (nationalism, patriotism), efforts, activities, participation, and responsibility of citizens (Saputra, 2017; Saputra et al., 2020). In this way, citizens not only teach the provisions of the constitution or articles of the Constitution but also reflect the relationship between the behavior of citizens and the natural environment in everyday life. Strengthening the harmonious and peaceful attitude of fellow citizens can be integrated into the curriculum because such activities can increase students' knowledge and understanding of others, accept differences, improve communication with others, increase solidarity and increase cooperation with others (Karliani, 2014; Wagiono et al., 2020).

Therefore, civic education for the generation of young citizens with an archipelago of insight and national resilience in the nation's prospective successors, the role of teachers applying lear;ning innovation in education becomes an important point to note in this regard. Systematically identify the skills needed to teach in the context of blended learning. Then develop, establish and test instruments that can be used to determine the readiness of students and the entire school for blended learning teaching (Graham, Borup, Pulham, \& Larsen, 2019). Blended learning context in the learning implementation guidelines for teachers to prepare some learning videos, text, photos, sounds, or images that are by PPKn (Suhartono, 2016). 


\section{Steps to Implement Blended Learning During the COVID-19 Pandemic Civic Education Subjects at Muhammadiyah 1 Kroya Junior High School}

Steps to implement blended learning during the COVID-19 pandemic are charged with the character of civic education subjects of Muhammadiyah 1 Kroya Junior High School students, namely (1) The first step is to formulate learning achievements in blended learning system design, such as establishing, identifying, sorting, strategizing, selecting learning materials, and determining how to evaluate learning outcomes. (2) The second step, mapping, and organizing learning materials are to describe and compile learning material into the core of the discussion, sub-subject of discussion, and discussion of materials in accordance with learning achievements. (3) The third step is to define and define synchronous and asynchronous learning activities. This determines whether the main content of the discussion or sub-discussion can be understood in a synchronous or asynchronous strategy. (4) The next step is to learn with a synchronous strategy, understand what is learned by creating asynchronous learning design, then determine the synchronous learning activity. Synchronous learning is the process of learning between teachers and students at the same time but in different locations. The learning process is usually done using information communication technology media in the form of audiovisual conference videos. (5) Designing asynchronous learning activities after identifying discussions that are understood as asynchronous learning, namely developing asynchronous learning design. Next plan various digital resources, related online discussion forums, related online tasks, and relevant assessments. Blended learning design model on online learning with asynchronous strategy has four values: learn (learning), deepening, application, and evaluation (assessment/measurement) (Katz, 2012)

Synchronous learning is not much different from face-to-face learning, wherein synchronous learning the learning process consists of (a) Opening activities; The teacher provides or airs learning videos that have been uploaded on youtube, pictures of current issues according to PPKn material, then ask students to analyze and respond, the teacher explains the material that has been studied and discussed and the learning goals to be achieved at the meeting. (b) Core activities; Teachers provide reading material, PPT, PPKn learning videos that have been uploaded on youtube, images of current issues according to PPKn subjects, then students are divided into small groups of 4-5 people with heterogeneous ability to discuss, observe, and present. In addition, teachers provide opportunities for learners to ask factual, conceptual, procedural, and metacognitive questions in Whatsapp chat columns, google classroom, google meet, and so on. Teachers and students collect various information from the material that has been presented. (c) Closing activities; The teacher asks students to summarize/ conclude important points that arise from the material that has been discussed, then the teacher provides feedback and reinforcement to the learning outcomes that have been discussed, and finally the provision of individual assignments or independent assignments to students. During the learning process, the teacher observations the activeness of each student.

Learning activities effectively and comfortably in online classes are where the situation is conducive. This makes students trained to ask questions, do tasks, express ideas, and achieve material and learning because they feel free to argue comfortably (informant RK, interview September 1, 2021). When learning takes place on an internet network, the teacher should liven up his learning atmosphere by repeatedly providing stimulus that encourages students to communicate regularly with the teacher (Prayitno, 2015). 
In today's era, we live in the digital age, with its emergence as a source of information and communication that affects every aspect of people's lives. This influence will not only be in social life but also in the world of education. The use of gadget media for blended learning with character-laden PPKn subjects by students effectively enough is a new strategy for teachers to communicate with students and parents in providing digital platforms of educational information services related to school learning programs (Wagiono et al., 2020). Student self-assessment, fellow students' assessment, and teacher assessment are learning development processes that can be used by analytical results for blended learning (Yuliyana et al., 2021). The complexity of learning in the era of industrial revolution 4.0 is overcome by the use of information technology gadgets. Learning is applied with blended learning as a means of online learning is the new normal era during the COVID 19 pandemic to realize education 4.0, producing graduate output students who have or have good problem-solving skills. The learning model needed in pandemic times and to answer the challenges of the industrial revolution 4.0 today is a learning model that provides training to learners to think critically, creatively, and innovatively (Aritonang et al., 2021). Where learning not only emphasizes the transfer of knowledge but also the learning process that results in students who are creative, critical, innovative, and collaborative in solving problems. It is expected that learners can apply the values of character responsibility of honesty, justice, love of the homeland, democracy, and cooperation ( $\mathrm{NH}$ informant, interview September 1, 2021).

\section{Conclusion}

Curriculum development is an educational design that summarizes the learning offered to students. Some of these are integrated into the curriculum, including personality values, knowledge, educational behavior, and skills (Wagiono \& Karliani, 2020). Millennial youth are increasing the use of the internet as information technology that is closely related to gadgets. The application of blended learning during the COVID-19 pandemic civic education subjects in millennials in Junior High School of Muhammadiyah 1 Kroya is character-laden. In the current new normal era, online learning with blended learning becomes an optimal learning alternative. Online learning stage with blended learning among others (1) The presentation of the material provided should be seen by students before the start of learning in the form of PowerPoint (PPT), Pdf, Ms. Word, images of current issues, videos that have been uploaded on youtube by teachers on learning management systems such as google classroom, Whatsapp, zoom, and google meet. (2) Teachers should conduct guidance and discussion of asynchronous material. In online learning, teachers must provide guidance columns that are not limited by the time such as discussions through video chat, mailing list, and forum discussion. (3) Teachers hold practices or demonstrations for students and conduct evaluations in the form of oral, written tests, quiz games, project learning, PTS, and PAS that are included in Google Drive, web, or technology media as a means of measuring capability. The results showed that gadget-based blended learning activities serve as a means of education, evaluation, and information for millennials. It is expected that blended learning in Civic education subjects will be applied to digital media to overcome the condition of students having diverse abilities, the number of students, and the dense learning in the new normal era during the COVID-19 pandemic. Students can understand PPKn material in youtube educational videos and images presented by teachers. 


\section{References}

Afandi, M., Chamalah, E., dan Wardani, O. P. (2018). Model dan Metode Pembelajaran di Sekolah. Jurnal Kependidikan, 2(UNISSULA Press), 50-72.

Aritonang, I. B., Martin, R., \& Akbar, W. (2021). Peran Model Pembelajaran Blanded Learning Dalam Masa Pandemi COVID-19 Terhadap Hasil Belajar PPKN di Kelas V UPTD SPF SDN Teluk Rumbia. Jurnal Kependidikan, 1(1), 1-14.

Arizal, A., Sukmana, R. A., Ulfah, Y., Shaddiq, S., \& Zainul, M. (2021). Strategi Pemanfaatan Facebook Marketplace dalam Manajemen Periklanan. Syntax Idea, 3(6), 1278-1289.

Černá, M., \& Svobodová, L. (2015). Development of financial and language competences via on-line games and tests. Proceedings of the European Conference on E-Learning, ECEL.

Emi, M. (2015). Budaya Baca di Era Digital. Lembaga Ladang Kata.

Fadilurrahman, M., Ramadhani, R., Kurniawan, T., Misnasanti, M., \& Shaddiq, S. (2021). Systematic Literature Review of Disruption Era in Indonesia: The Resistance of Industrial Revolution 4.0. Journal of Robotics and Control (JRC), 2(1), 51-59.

Graham, C. R., Borup, J., Pulham, E., \& Larsen, R. (2019). K-12 blended teaching readiness: Model and instrument development. Journal of Research on Technology in Education, 51((3)), 239-258.jj.

Hamidi, J. (2010). Civic Education (Antara Realitas Politik dan Implementasi Hukumnya). Jurnal Civicus, Vol. X(Edisi Juni 2006), Bandung : Lab PKn UPI Bandung.

Iyansyah, M. I., Sari, S., Shaddiq, S., \& Zainul, H. M. (2021). Literasi Manajemen Komunikasi Pemasaran dalam Melaksanakan Etika dan Standar Periklanan. Jurnal Revolusi Indonesia, 1(10), 1073-1091.

Kalida, M. \& M. M. (2015). Gerakan Literasi Mencerdaskan Negeri. Aswaja Pressindo.

Karliani, E. (2014). Membangun Civic Engagement Melalui Model Service Learning Untuk Memperkuat Karakter Warga Negara. Jurnal Pendidikan Pancasila Dan Kewarganegaraan, 27(2), 71-78.

Katz, J. (2012). (2012). Teaching to diversity: The three-block model of universal design for learning. Portage \& Main Press.

Moser, A., \& Korstjens, I. (2018). Series: Practical guidance to qualitative research. Part 3: Sampling, data collection and analysis. European Journal of General Practice. https://doi.org/https://doi.org/10.1080/13814788.2017.1375091.

Petrova, A., \& Podzygun, O. (2018). Implementation of information and communication technologies in teaching a foreign language for professional communication. Professional competency of modern specialist: means of formation, development and improvement. 163- 
176.

Prayitno, W. (2015). Implementasi Blended Learning dalam Pembelajaran pada Pendidikan Sekolah Dasar dan Menengah. Jurnal Pendidikan, 6(01).

Rizal, R., Misnasanti, M., Shaddiq, S., Ramdhani, R., \& Wagiono, F. (2020). Learning Media in Indonesian Higher Education in Industry 4.0: Case Study. International Journal on Advanced Science, Education, and Religion, 3(3), 127-134.

Saputra, M. R. Y., Winarno, W. W., Henderi, H., \& Shaddiq, S. (2020). Evaluation of Maturity Level of the Electronic based Government System in the Department of Industry and Commerce of Banjar Regency. Journal of Robotics and Control (JRC), 1(5), 156-161.

Shaddiq, S., Haryono, S., Muafi, M., \& Isfianadewi, D. (2021). Antecedents and Consequences of Cyberloafing in Service Provider Industries: Industrial Revolution 4.0 and Society 5.0. The Journal of Asian Finance, Economics, and Business, 8(1), 157-167.

Shaddiq, S., Putera, A.R., Aisyah, L., Misnasanti, \& Mahfuzah, A. (2021). A Nexus among Reliability Improvement of Distribution System with Optimal Placement and Capacity of Wind-Based Distributed Generation Management. Journal ICTEE, 2(2), 119.

Simonson, M. (2016). Annual Proceedings of Selected Research and Development Papers Presented at the Annual Convention of the Association for Educational Communications and Technology (39th, Las Vegas, Nevada, 2016). Volume 1. The Annual Convention of the Association for Educational Communications and Technology (39th, Las Vegas, Nevada, 2016).

Suhartono. (2016). Menggagas pendekatan blended learning di sekolah dasar. Prosiding Temu Ilmiah Nasional Guru (TING) VIII.

Tubagus Saputra. (2017). Pendidikan Kewarganegaraan Untuk Generasi Milenial. hlm.1-2.

Wagiono, F., \& Karliani, E. (2020). Implementation of School Literacy Program In Junior High School Muhammadiyah Palangka Raya. 5(2), 177-191.

Wagiono, F., Shaddiq, S., Sakman, S., \& Suprayitno, S. (2020). Implementation Based Education (Learning-Gradual) through Traditional Games Mambe Tampun. Jurnal Iqra': Kajian Ilmu Pendidikan, 5(2), 43-55.

Wagiono, F., Shaddiq, S., \& Syahidi, A. A. (2020). Pengembangan Pkn Di Era Generasi Millenial Berbantuan M-Learning (Mobile Learning) Pada Gadget Pembelajaran Berbasis Cooperative Learning Bermuatan Karakter. Edunesia: Jurnal Ilmiah Pendidikan, 1(3), 63-72. https://doi.org/10.51276/edu.v1i3.64.

Wahana, H. D. (2015). Pengaruh Nilai-Nilai Budaya Generasi Millennial dan Budaya Sekolah Terhadap Ketahanan Indivdu (Studi di SMA Negeri 39, Cijantng, Jakarta). 
Jurnal Ketahanan Nasional, Vol.9, XXI, hlm. 14-22.

Wanidison, E., \& Shaddiq, S. (2021). Training Programs Needed to Develop Young Entrepreneurs From Training Institutions in Bandung: A Qualitative Perspective. Strategic Management Business Journal, 1(1), 28-39.

Wijaya, B. A., Noveriady, M., Puspaningratri, N., \& Shaddiq, S. (2021). The Role of Corporate Marketing Communications Management in Implementing Advertising Ethics and Standards. Jurnal Mantik, 5(2), 807-811.

Wuryan dan Syaifullah. (2008). Civics: Ilmu Kewarganegaraan (p. hlm. 9). Laboratorium Pendidikan Kewarganegaraan UPI.

Yuliyana, M., Rochmiyati, R., \& Maulina, D. (2021). Blended Learning Assessment Instrument For Elementary School. Edunesia: Jurnal Ilmiah Pendidikan, 2(3), 668-676. https://doi.org/10.51276/edu.v2i3.189.

https://www.liputan6.com/news/read/4589350/update-corona-23-juni-20212033421positif-covid-19-sembuh-1817303-meninggal-55594. 